\title{
Professional Standards Training and Understanding Pre-School Teachers' Knowledge about Professional Standards
}

\author{
Nguyen Thi Hien ${ }^{1}$, Mai Van Hung ${ }^{2 *}$ \\ *Corresponding Email: hungmv@vnu.edu.vn \\ ${ }^{1}$ Department of Preschool Education, Ministry of Education and Training, Vietnam \\ ${ }^{2}$ Department of Biology Education, VNU University of Education, Vietnam
}

Received: March 15, 2021

Revised: April 26, 2021

Accepted: May 7, 2021

\begin{abstract}
Theimprovement of the teacher's quality, including teachers in general and preschool teachers in particular, hasgained interested in many countries around the world. Currently, most countries in the world have issued a framework of competency or professional standards for teachers as a basis for preschool teachers to self-assess and be assessed for their qualities and competenciet. On that basis, preschool teachers can implement the plan of quality training, strengthen and improve professional expertise. This article, the author conducts research to evaluate the implementation of the professional standards manual of schools and the teacher's understanding of professional standards. This is considered an important factor that will contribute to improving the effectiveness of teacher ratings according to professional standards. In this study, the author uses mainly quantitative research methods (survey, descriptive statistics and inference statistics) to clarify the problems that the research has posed. Research results show that there is a relationship between standard manual training and preschool teachers' understanding of professional standards. Standards instructors have a good understanding of professional standards. Especially the training is organized by the school and the education and training department, so the training classes are small, with a small number of participants and therefore higher quality.
\end{abstract}

Keywords: Professional Standards, Preschool Teachers, Standard Instruction Training, Standard Knowledge

\section{Introduction}

The improvement of the teacher's quality, including teachers in general and preschool teachers in particular, has gained interested in many countries around the world. The Vietnam Education Law states: "Teachers have a decisive role in ensuring the quality of education, have an important position in the society, be honored; The State adopts a policy of training and fostering to improve the political and professional qualifications of teachers; Educational institutions have the responsibility to create conditions for teachers to be trained to meet the prescribed standards" (Assembly, 2019). For preschool/early childhood education, one of the important tasks of teachers is " implementing the work of nurturing, caring for and educating children according to the preschool education program: making care and education plans; Building an educational environment, organizing activities to nurture, care for and educate children; Child assessment and management; Take responsibility for the quality of child nurturing, caring and education" (Training, Circular No. 52/2020 / TT-BGDĐT, dated 30/12/2020 Issuing Preschool Regulations, 2020)

In order to measure and clearly assess the capacity to perform the task of nurturing, caring for and educating pre-school children, most countries around the world have enacted competency frameworks or professional standards. In Vietnam, the Ministry of Education and Training has 
issued professional standards for preschool teachers together with Circular No. 26/2018 / TTBGDĐT dated October 8, 2018. The purpose of issuing standards is "to serve as a basis for preschool teachers to self-assess and be assessed for their qualities and competencies, on that basis to develop and implement plans for quality training, fostering to improve their skills. professional and professional force to meet the requirements of educational innovation" (Training, Circular No. 26/2018 / TT-BGDĐT promulgating professional standards for preschool teachers, 2018).

However, according to the summary report of the Ministry of Education and Training, "teacher evaluation results according to formal standards, so the assessment results are not accurate, teachers have not been classified yet, and the current situation has not been given. determine the exact number of teachers and the content to be fostered in order to raise standards and improve professional capacity" (Training, Circular No. 26/2018 / TT-BGDĐT promulgating professional standards for preschool teachers, 2018). This is relevant to the implementation of the teacher's career standard manual and level of awareness. In this study, we conduct research on the topic "instructional training and of preschool teachers about professional standards" (Training, Guide of Q\&A for preschool teachers, Education Publishing House of Vietnam, 2019). The research results will be the basis for proposing recommendations in the implementation of using standards in preschool education institutions.

The research is conduct in order to evaluate the teacher's professional standards and the teacher's knowledge about the standards. The research results will be the basis for proposing recommendations in the implementation of using standards in preschool education institutions.

\section{Methods}

This study employs survey method by using questionnaires to collect information on teachers and administrators' perceptions of professional standards and participating training classes. Descriptive statistical method: Describe and analyze the collected survey data related to the manual training of standards and knowledge of preschool teachers about professional standards. Statistical inference method: the relationship between standard manual training and knowledge of preschool teachers about professional standards

\section{Results and Discussion}

\section{The participation in training and fostering use the professional standards of preschool teachers}

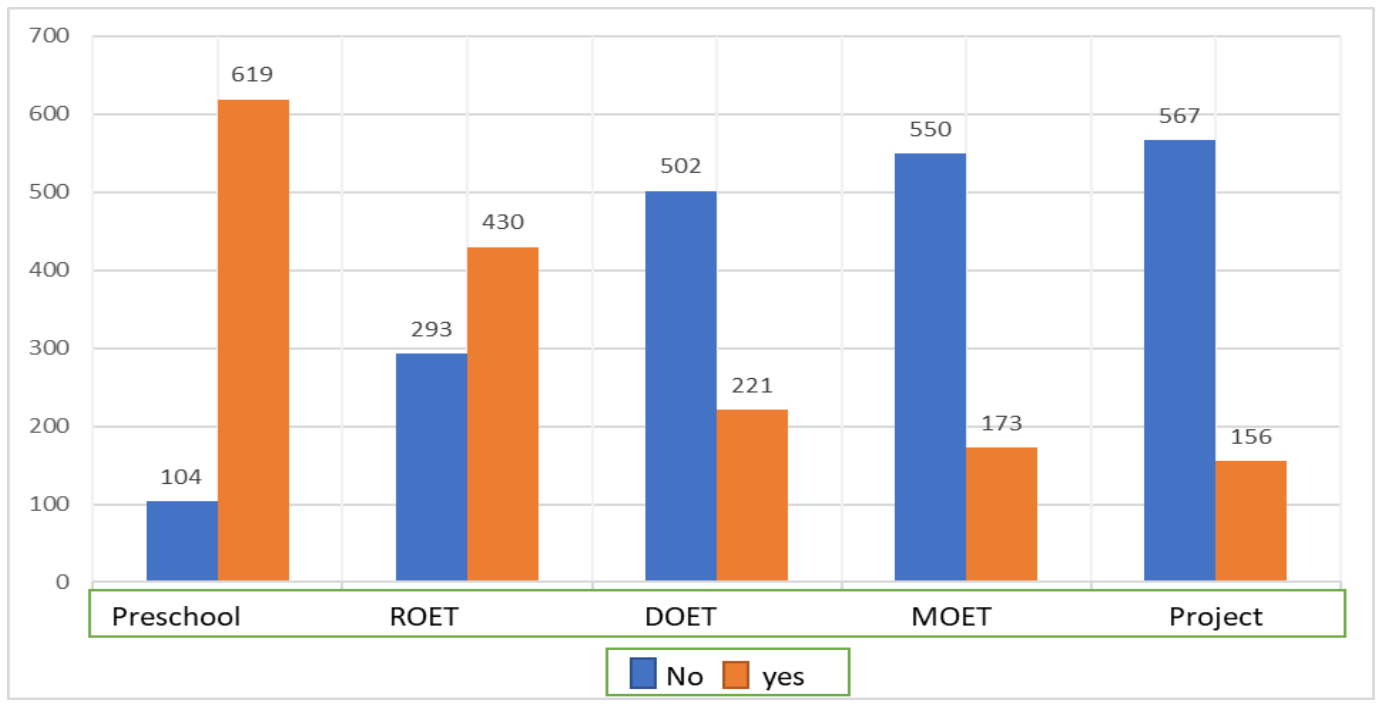

Figure 1. Number of preschool teachers participating in training courses about the professional standards of preschool teachers 
As it can be seen from figure, $100 \%$ of preschool teachers have been trained in how to use the standards either by the preschool level or department or department or ministry level (in which the Project and Project does not have). According to decentralized management, when the standard is promulgated, the Ministry of Education and Training issues documents and standard manuals, on which basis the Department of Education and Training will deploy training and guidance for Education - Training rooms. The number of preschool administrators and teachers involved at the department and department level will be the core to the implementation of guidance for preschool teachers in preschool education institutions.

Some managers and preschool teachers also agreed with the survey results, however, there is an opinion that: "Teachers have to work for extra hours (8-9 hours). even up to 10-11 hours / day), so there is no time left to read or study the standard document. Some places have not carefully instructed the evidence collection, leading to incorrect understanding, and difficulty in collecting infomation. Therefore, in order to raise the teacher awareness of preschool teachers about the Career Standards, it is necessary to pay attention to training courses; Along with that should focus on training courses on how to rate results and collect evidence - training courses on how to directly implement the Professional Standards in the working process will bring good results than for the preschool teacher's level of the awareness of the Career Standards (Stansbury \& Zimmerman, 2000; Kennedy, 2016).

\section{Management staff and preschool teachers' awareness of Career Standards}

The authors surveyed 723 subjects about their awareness of the preschool teacher professional standards through 7 items, and were encoded in the following table.

Table 1. Coding question

\begin{tabular}{|c|l|}
\hline Code & \multicolumn{1}{c|}{ Content } \\
\hline Q1 & $\begin{array}{l}\text { Understand the purpose of promulgating regulations on professional standards for } \\
\text { preschool teachers }\end{array}$ \\
\hline Q2 & Understand the role and duties of early childhood teachers in career standards \\
\hline Q3 & Understand the criteria that directly affect professional skills \\
\hline Q4 & $\begin{array}{l}\text { Understand when to adjust nurturing and health care planning towards the } \\
\text { comprehensive development of children }\end{array}$ \\
\hline Q5 & Distinguish the levels of criteria on child nurturing, health care and education \\
\hline Q6 & Know how to gather your proof that is consistent with the professional benchmarks \\
\hline Q7 & $\begin{array}{l}\text { Know how to protect your rights when you are not satisfied with the results of the } \\
\text { professional standard rating }\end{array}$ \\
\hline $\begin{array}{l}5.000 \\
4.800 \\
4.600 \\
4.400 \\
4.200 \\
4.000 \\
3.800\end{array}$ \\
$\begin{array}{l}3.600 \\
3.400\end{array}$ \\
3.200 \\
3.000
\end{tabular}

Figure 2. Preschool administrators \& teachers' understanding of career standards 
In general, the participant respond "totally agree" with the surveyed contents about professional standards (average are over 4.2 / 5). In particular, the assessment of managers is higher than preschool teachers in all criteria, it shows that managers who are working in preschool institutions have very good awareness of standards. career, through which there are appropriate instructions at the workplace.

In addition, among 7 assessed contents, the survey subjects assessed the content "Knowing how to gather proofs in accordance with the professional standards" at the lowest level of the 7 contents $(4.24 / 5)$ - The results show that this is the content that still has difficulty in working with professional standards.

To evaluate the effectiveness of these training courses, the authors assessed the relationship between the preschool teacher's level of knowledge and the preschool teacher training courses attended through the Pearson correlation coefficient.

Table 2. The evaluation of the correlation of training on Standards with the awareness of preschool teachers

\begin{tabular}{|c|c|c|c|c|c|c|c|c|}
\hline & Q1 & Q2 & Q3 & Q4 & Q5 & Q6 & Q7 & $\begin{array}{l}\text { General } \\
\text { assessment }\end{array}$ \\
\hline $\begin{array}{l}\text { Preschool } \\
\text { education } \\
\text { institution }\end{array}$ & -0.229 & -0.229 & $-0.298^{*}$ & -0.078 & -0.085 & -0.177 & -0.165 & 0.042 \\
\hline $\begin{array}{l}\text { Education } \\
\text { and Training } \\
\text { Department }\end{array}$ & 0.161 & 0.161 & $0.249 *$ & $0.274^{*}$ & $0.348 * *$ & $0.322 * *$ & 0.048 & $0.162 * *$ \\
\hline $\begin{array}{l}\text { Department } \\
\text { of Education } \\
\text { and Training }\end{array}$ & $\begin{array}{l}0.320 \\
* *\end{array}$ & $0.320 * *$ & $0.372 * *$ & $0.369 * *$ & $0.286^{*}$ & $0.353 * *$ & $0.253^{*}$ & 0.016 \\
\hline $\begin{array}{l}\text { Ministry of } \\
\text { Education } \\
\text { and Training }\end{array}$ & 0.031 & 0.031 & -0.086 & -0.008 & -0.166 & -0.171 & 0.100 & $-0.096 * *$ \\
\hline $\begin{array}{ll}\text { Through } & \\
\text { topics } \\
\text { projects }\end{array}$ & -0.137 & -0.137 & 0.001 & -0.211 & -0.198 & $-0.239 *$ & -0.053 & $-0.143 * *$ \\
\hline $\begin{array}{l}\text { Training on } \\
\text { assessment } \\
\text { process } \\
\text { guidance }\end{array}$ & -0.179 & -0.179 & -0.061 & -0.193 & -0.231 & $-0.292 *$ & -0.122 & 0.035 \\
\hline $\begin{array}{l}\text { Training on } \\
\text { how to rate } \\
\text { the results }\end{array}$ & 0.210 & 0.210 & 0.159 & $0.419 * *$ & $0.372 * *$ & $0.349 * *$ & 0.142 & 0.006 \\
\hline $\begin{array}{l}\text { Training on } \\
\text { how to collect } \\
\text { proof }\end{array}$ & $\begin{array}{l}0.281 \\
*\end{array}$ & $0.281^{*}$ & $0.245^{*}$ & $0.380 * *$ & $0.303^{*}$ & $0.329 * *$ & $0.251^{*}$ & 0.027 \\
\hline
\end{tabular}


The results of assessing the correlation between the participation in training courses on the level of knowledge show that the training courses of the Department of Education and Training and the Department of Education and Training have a positive effect on the level of knowledge. Career Standards for preschool teachers. In particular, the training courses on how to collect evidence have a very good effect on all 7 criteria about the level of knowledge of preschool teachers about Professional Standards.

The general assessment of the correlation between the training and fostering in using Standards with preschool teachers' awareness shows that the training courses of preschool institutions, the Department of Education and Training and the Department of Education Education - Training has a positive influence on the knowledge of preschool teachers about standards, especially training by the Education and Training Department (Cunningham et al., 2009; Sandvik et al., 2014; Zaslow et al., 2010; Cabell et al., 2011; Zinsser et al., 2014). The large-scale training has not brought direct effects on changing the awareness of preschool teachers about professional standards (Piasta et al., 2017; Sheridan et al., 2009; Pianta et al., 2009). However, training courses on guiding the evaluation process have not been very effective.

Based on research results, to improve the effectiveness of professional standards for teacher evaluation, the author has a number of recommendations for preschool education institutions.

Based on results of training in standard manuals and teachers' knowledge of standards, preschool institutions show that standard instruction training is very necessary. Is it effective or not due to whether the teacher understands the standards and knows how to evaluate or not. Therefore, it is necessary to focus on strengthen and guiding training in small groups.

Create a working environment where preschool teachers have a chance to be listened, empathized and assessed with fairness; teachers are able to speak out their opinions; Managers are always open and friendly; build a healthy working environment, do not put psychological pressure on teachers. Regularly, helps are provided to support teachers so they know how to collect and maintain assessment evidence and self-assessments according to standards.

\section{Conclusion}

The authors use a combination of research methods to solve the research questions and research hypotheses, specifically: Based on the survey results, it shows that preschool members have a clear understanding of the Career Standards. To evaluate the effectiveness of these training courses, the author evaluated the relationship between the knowledge level of preschool trainers and the preschool trainers attended through the Pearson correlation coefficient. The results show that the training courses of preschool institutions, the Department of Education and Training and the Department of Education and Training have a positive impact on the change (preschoolers will have a good change when attending training courses) - especially the training provided by the Education and Training Department with $99 \%$ significance level. Large-scale training courses have not been very effective, paying attention to training courses that focus on training courses on how to rate results and collect evidence - training courses on how Direct implementation of Career Standards in the working process will bring a better effect on preschoolers' level of understanding of Career Standards.

\section{References}

Cabell, S. Q., Justice, L. M., Piasta, S. B., Curenton, S. M., Wiggins, A., Turnbull, K. P., \& Petscher, Y. (2011). The impact of teacher responsivity education on preschoolers' language and literacy skills.

Cunningham, A. E., Zibulsky, J., \& Callahan, M. D. (2009). Starting small: Building preschool teacher knowledge that supports early literacy development. Reading and Writing, 22(4), 487-510. 
Kennedy, M. M. (2016). How does professional development improve teaching?. Review of educational research, 86(4), 945-980.

Nguyen Ba Minh. (2019), Guide to building education plans in Vietnamese educational institutions. Vietnam Education Publishing House.

Pianta, R. C., Barnett, W. S., Burchinal, M., \& Thornburg, K. R. (2009). The effects of preschool education: What we know, how public policy is or is not aligned with the evidence base, and what we need to know. Psychological science in the public interest, 10(2), 49-88.

Piasta, S. B., Justice, L. M., O'Connell, A. A., Mauck, S. A., Weber-Mayrer, M., Schachter, R. E., ... \& Spear, C. F. (2017). Effectiveness of large-scale, state-sponsored language and literacy professional development on early childhood educator outcomes. Journal of Research on Educational Effectiveness, 10(2), 354-378.

Sandvik, J. M., Van Daal, V. H., \& Adèr, H. J. (2014). Emergent literacy: Preschool teachers' beliefs and practices. Journal of Early Childhood Literacy, 14(1), 28-52.

Sheridan, S. M., Edwards, C. P., Marvin, C. A., \& Knoche, L. L. (2009). Professional development in early childhood programs: Process issues and research needs. Early education and development, 20(3), 377-401.

Stansbury, K., \& Zimmerman, J. (2000). Lifelines to the Classroom: Designing Support for Beginning Teachers. Knowledge Brief.

Zaslow, M., Tout, K., Halle, T., Whittaker, J. V., \& Lavelle, B. (2010). Toward the Identification of Features of Effective Professional Development for Early Childhood Educators. Literature Review. Office of Planning, Evaluation and Policy Development, US Department of Education.

Zinsser, K. M., Shewark, E. A., Denham, S. A., \& Curby, T. W. (2014). A mixed-method examination of preschool teacher beliefs about social-emotional learning and relations to observed emotional support. Infant and Child Development, 23(5), 471-493. 